\title{
Development and infrastructure of the Federated States of Micronesia
}

\author{
M. Haga ${ }^{1}$, O. Hanada ${ }^{1}$, N. Takahashi ${ }^{2}$, N. Kusakabe ${ }^{3}$, H. Gotoh ${ }^{4}$, \\ Y. Maeno ${ }^{4} \&$ M. Takezawa ${ }^{4}$ \\ ${ }^{1}$ Asia Agriculture Forum, NPO, Japan \\ ${ }^{2}$ Japan Organization of Legend, Culture \& Art, Japan \\ ${ }^{3}$ OB Express Ltd., Japan \\ ${ }^{4}$ Nihon University, Japan
}

\begin{abstract}
The rise in sea levels associated with global warming is a very serious issue in the 607 islands that constitute the Federated States of Micronesia (FSM). The islands range in altitude and size from sea level to $791 \mathrm{~m}$, and approximately $702 \mathrm{~km}^{2}$, respectively. The total length of the coastline is $6,112 \mathrm{~km}$ and the population numbers approximately 111,000 people. Infrastructure in the FSM is varied. Electricity is primarily generated by diesel generators, but there are two small hydroelectric facilities and solar power is becoming increasing popular on the outer islands. Though rainfall is plentiful in the four states that make up the FSM, water supply by public water works is not consistent. Residents therefore supplement their water requirements by using individual rainfall watershed. Steady improvements in the reliability of the public water supply are continually being made. The urban centers of the four states of the FSM have public water and sewer systems. Water seal and dry composting toilets are being more widely deployed, particularly in remote villages and the outlying islands. Each of the four urban centers also has an international airport that is capable of accommodating mid-sized jets, and each airport has new air terminals designed to meet the increasing needs of air traffic. All state centers in the FSM have deep draft harbors capable of handling almost all commercial shipping needs. Each of the ports also provides containerized cargo handling, some warehousing, and transhipment facilities. Service to anywhere in the world is provided through a variety of lines which generally operate on a monthly schedule. This paper
\end{abstract}


discusses how the FSM can protect its infrastructure from disasters such as tsunamis or flood tides, as well as thrive as a tourist and industrial hub. Keywords: global warming, sea-level rise, island, coral reef, tourism.

\section{Introduction}

The Federated States of Micronesia (FSM) constitutes a subregion of Oceania that is made up of many small islands in the western Pacific Ocean. The FSM consists of four island states, with Yap in the west, through to Chuuk, Pohnpei and Kosrae in the east. The FSM is comprised of approximately 607 islands spread over almost 2,700 km just north of the equator, approximately 4,000 km southwest of the main islands of Hawaii. More specifically, the islands are about 2,900 km north of eastern Australia, northeast of New Guinea, south of Guam and the Marianas, west of Nauru and the Marshalls, and east of Palau and the Philippines. The total land area of the FSM is approximately $702 \mathrm{~km}^{2}$ and each of four main states of the country is centered on one or more of the larger highlying islands [1]. Like many of the Micronesian countries and Marshall Islands in the western Pacific Ocean, the FSM faces the threat of rising sea levels due to increased global warming. The Inter-government Panel of Climate Change (IPCC) reported that $80 \%$ of the land in the Micronesian and Marshall islands will be covered by $1 \mathrm{~m}$ of water if the ocean level continues to rise, so that the beach of the beautiful coral reef will be disappeared if the measure for a rise in the ocean will be not taken [2]. This study will examine the measures that have been developed for implementation by the FSM in the event of a rise in sea levels due to global warming.

\section{Federated States of Micronesia (FSM)}

The FSM was formerly a part of the Trust Territory of the Pacific Islands, a United Nations Trust Territory administered by the USA. However, the FSM formed its own constitutional government in 1979 and became a sovereign state after obtaining independence under the Compact of Free Association with the USA in 1986. European explorers reached the Caroline Islands to the south of the FSM in the $16^{\text {th }}$ century, Germany assumed control of the islands in 1899 , and then Japan assumed control in 1914. Under the auspices of the United Nations, the United States administered in the FSM until 1947 as part of the Trust Territory of the Pacific Islands. In 1979, four of the Trust Territory districts (Yap, Chuuk, Pohnpei and Kosrae) ratified a new constitution to become the FSM. The new constitution guaranteed fundamental human rights and established the separation of governmental powers. The FSM signed a Compact of Free Association with the USA in 1986, and the Compact was renewed in 2004. The 607-island nation that constitutes the FSM is one of the most remote and beautiful places on earth. Friendly and peaceful, it encompasses an area of approximately $3000 \mathrm{~km}$ of ocean north of the equator that is home to cultural and biological diversity that is unrivaled anywhere else (Fig. 1). The FSM is situated in the heart of the Caroline Island Archipelago, a vast seascape that extends from 
Palau in the west to Kiribati in the east. Geologically, the FSM consists of two island-types: high volcanic islands, such as Pohnpei Island, the Chuuk Lagoon Islands, Kosrae Island, which is sedimentary, and low-lying coral atolls. Pohnpei, Chuuk and Kosrae are characterized by steep, rugged upland areas, whereas the upland areas of Yap Island are more gently sloping and surrounded by substantial, often swampy lowlands. The islands were originally covered by natural forests, but the natural upland forests are rapidly being converted to agroforestry or secondary vegetation; consequently, large areas of forest now only remain on the islands of Pohnpei and Kosrae. The location of the FSM is shown in Fig. 1 and Table 1 shows the land area and population of each state [3].

Table 1: $\quad$ Land area and population of the main islands of the FSM [3].

\begin{tabular}{|c|c|c|c|c|}
\hline State & Capital & Area $\left(\mathrm{km}^{2}\right)$ & $\begin{array}{c}\text { Population } \\
(\text { people })\end{array}$ & $\begin{array}{c}\text { Population density } \\
\left(/ \mathrm{km}^{2}\right)\end{array}$ \\
\hline Chuuk & Weno & 127 & 54,595 & 420 \\
\hline Kosrae & Tofol & 110 & 9,686 & 66 \\
\hline Pohnpei & Kolonia & 345 & 34,685 & 98 \\
\hline Yap & Sebastian Anefal & 118 & 16,436 & 94 \\
\hline
\end{tabular}

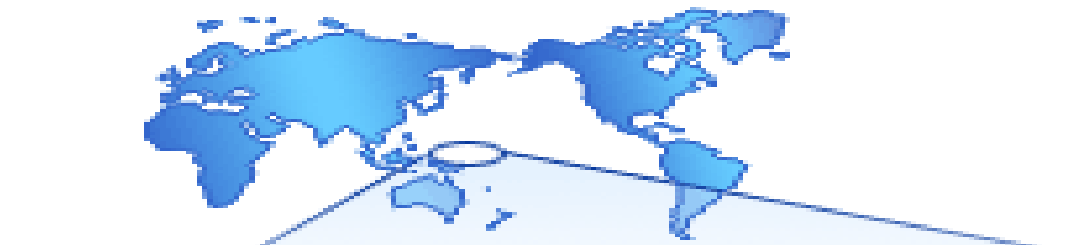

FEDERATED STATES OF MICRONESIA

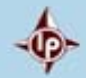

$P A C I F I C$ OCEAN

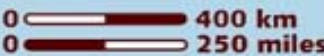

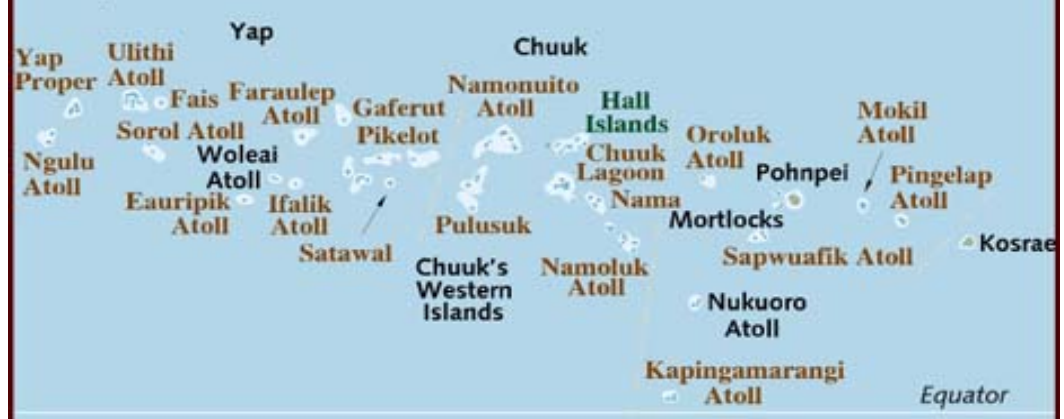

PACIFIC OCEAN

Figure 1: The location (top) and islands (bottom) of the Federated States of Micronesia [3]. 


\subsection{Chuuk Islands}

The Chuuk Islands $\left(152^{\circ} \mathrm{E} 7^{\circ} \mathrm{S}\right)$ consist of a group of islands surrounded by a very large atoll (Fig. 3). The outer barrier reef of the Chuuk Islands is punctuated by idyllic sand spits dotted with coconut palms and the high islands in the central lagoon rise up the blue island skies. Lush vegetation and simple living punctuate the lives of the lagoon. Local inhabitants are engaged in fishing, weaving and tending gardens. Chuuk Islands, with its vast, shallow, beautiful lagoon is a diving Mecca for wreck divers. The pace of life on the Chuuk Islands is slow and the tropical environment is easily observed and appreciated [4].

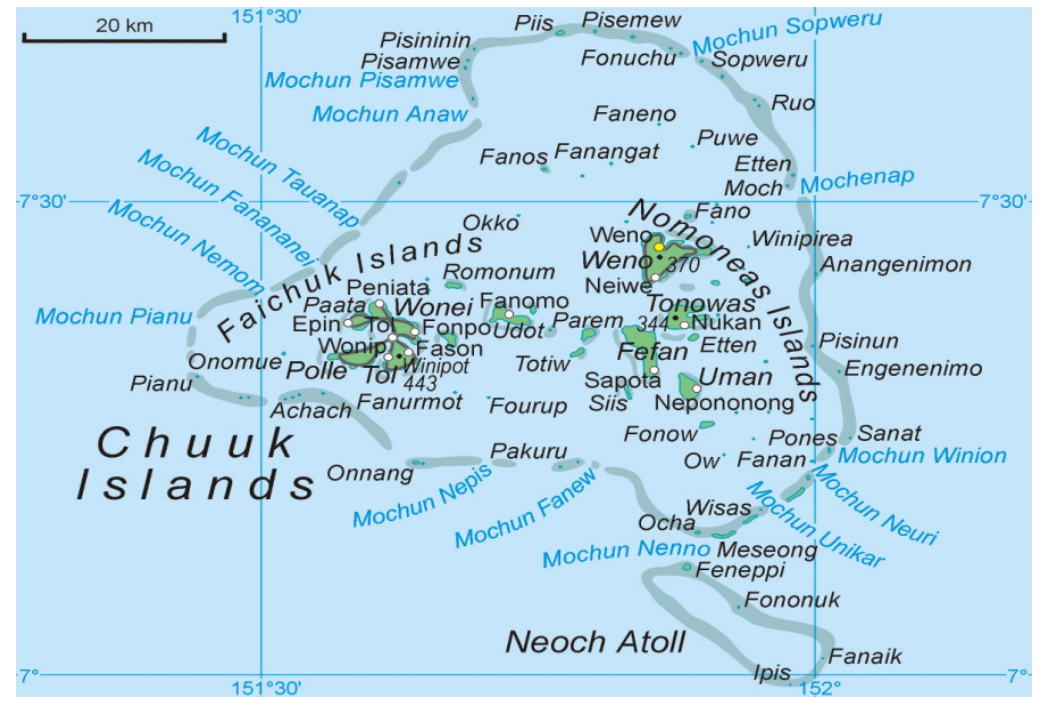

Figure 3: $\quad$ Chuuk Islands [4].

\subsection{Kosrae Islands}

The Kosrae Islands $\left(163^{\circ} \mathrm{E} 5^{\circ} \mathrm{S}\right)$ are known for their virgin reefs, pristine waters, and thriving hard coral communities (Fig. 4). The islands support more than 172 species of hard corals and there are over 250 species of fishes and other marine animals. Bottlenose dolphins are commonly observed along the coast and whales can occasionally be spotted. The tallest mountain on the islands is the majestic Mt. Finkol (634 m above sea level (ASL)) [5].

\subsection{Pohnpei Island}

Pohnpei Island $\left(158^{\circ} \mathrm{E} 7^{\circ} \mathrm{S}\right)$ is the largest and highest island in the FSM (Fig. 5). The considerable annual rainfall feeds more than 40 rivers which start in the lush highland rainforest. Largely surrounded by rich mangrove forests, Pohnpei's jagged coastline is intersected by numerous channels that carry nutrients into the vast lagoon. The hard coral reefs and colorful drop-offs of the island are 
enchanting and the fishing and diving are superb. Sharks, sea turtles and manta rays are frequently seen at many sites around the island [6]. The extension of the Pohnpei International Airport began in 2009, and it is anticipated that it will be completed in 2011. The Japanese Government has agreed to provide about US \$29 million for the entire project. The project includes extending the runway by $228 \mathrm{~m}$ and improving the terminal facilities and apron. And then, the total length of runway is extended from about $1,800 \mathrm{~m}$ to $2,000 \mathrm{~m}$ [7]. In the immediate future, the direct flight to the Pohnpei Island from many countries will be expected.

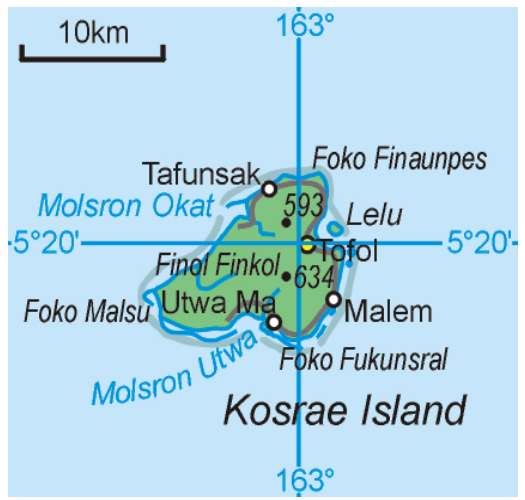

Figure 4: $\quad$ Kosrae Islands [5].

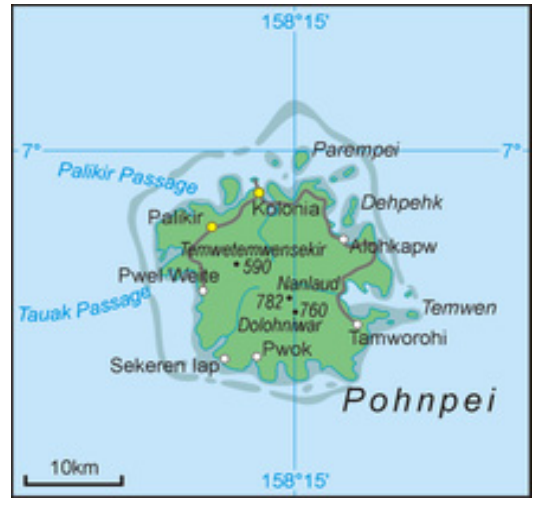

Figure 5: $\quad$ Pohnpei Islands [6].

\subsection{Yap Islands}

The Yap Islands $\left(138^{\circ} \mathrm{E} 9^{\circ} \mathrm{S}\right)$ are famous for their clear waters, where schools of tuna, dolphins and reef fish are found in abundance (Fig. 6). Observing the diverse marine life on the reefs and in the channels has become a must for divers around the world. Yap Islands are the world's foremost destination for seeing manta rays up close and personal [8].

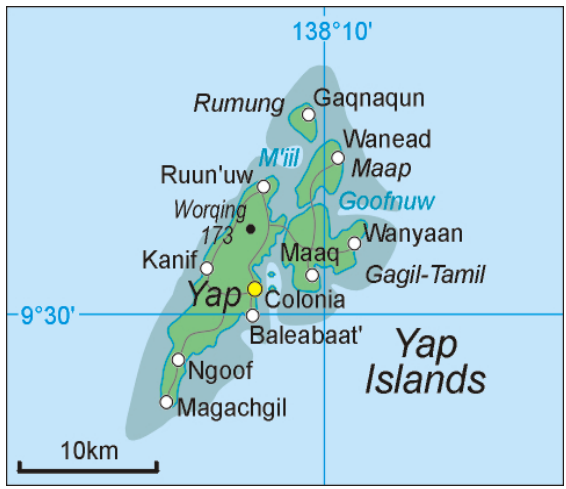

Figure 6: $\quad$ Yap Islands [7]. 


\section{Global warming and its effect on increasing sea levels}

Climate Change 2007, the Fourth Assessment Report (AR4) of the United Nations Intergovernmental Panel on Climate Change (IPCC), is part of a series of reports intended to assess scientific, technical and socio-economic information related to climate change, its potential effects, and options for adaptation and mitigation. The headline findings of the report were that "... warming of the climate system is unequivocal ...", and "... most of the observed increase in global average temperatures since the mid-20th century is very likely due to the observed increase in anthropogenic greenhouse gas concentrations." As the world's oceans rise, low-lying coastal areas will disappear, and flooding of coastal areas will become more common and more severe as storm surges will easily be able to reach low-lying areas. The occurrence of extreme high water events related to storm surges, high tides, surface waves, and flooding rivers will also increase. Flooding and loss of land will have significant impacts on humans, wildlife, and entire ecosystems. Migratory marine organisms will most likely be able to adapt. However, the rate of the rise in sea levels may adversely affect the successful migration of a number of organisms. As ocean levels rise, coastal and low-lying areas and ecosystems will be flooded. Higher sea levels will likely have significant impacts on the structure, function, and capacity of coastal and inland ecosystems, influencing their capabilities to perform ecosystem services. Coastal development also creates obstacles to plant and animal life, adversely affecting these species as they try to adapt to changes in the ecosystem. While mangroves would ordinarily reestablish themselves at the new low-tide zone, new buildings and other types of developments on the coast would now prevent this from happening. These changes in coastal and terrestrial ecosystems, and the resources they contain, will likely impact ocean circulation as well as sediment and nutrient flows in coastal areas. More than half of the world's population currently lives along the coast. Coastal areas are also economically important as they are generally resource-rich, and activities such as tourism, aquaculture, fisheries, agriculture, forestry, recreation, and infrastructure will all be markedly affected by rising sea levels. Rising sea levels will also increase both permanent and intermittent flooding of low-lying coastal areas across the world. Shorelines in Samoa have already retreated by as much as $5 \mathrm{~m}$, forcing residents to move to higher ground. Although a 3-4 mm per year rise in mean global sea level sounds small, encroaching oceans have already reclaimed two small uninhabited islands of Kiribati in the Central Pacific. They are also threatening the existence of lowlying nations, especially islands in equatorial regions. Tuvalu's population is quickly trying to adapt to this $5.7 \mathrm{~mm}$ rise in the sea level every year. Homes across the island have been made uninhabitable by flooding and buildings and other coastal developments have been destroyed by hurricanes and swells. Tuvalu will likely be one of the first nations to disappear as sea levels rise. Wholesale and partial relocation of populations living in severely affected areas such as Tuvalu, Bangladesh, and Samoa has already created climate change refugees. In areas where sea levels are not projected to rise as fast, vast infrastructure projects have been implemented to mitigate the impacts of rising 
sea levels, such as in the Netherlands and London. Residents of Tuvalu are also dealing with another effect of rising sea levels - contamination of groundwater resources through salt water intrusion. Scientists are looking at the history of the Floridian aquifer system as an example of what may happen to coastal aquifers if sea levels continue to rise. Concerns related to both water quantity and quality are increasing. In addition to seawater intrusion, increases in sea levels and flooding will likely have a number of impacts on terrestrial water storage, including rising water tables due to salt water intrusion, erosion, and impeding drainage. The potential public health impacts of continued increases in sea levels are staggering. Already, coastal zones in areas such as Tuvalu are experiencing contamination of groundwater resources and aquifers. Flooding, both permanent and intermittent, will allow diseases such as cholera and malaria to extend further inland. More frequent and intense severe storm events, such as hurricanes and monsoons, will also increase the incidence, occurrence, and exposure duration of local inhabitants to pathogens and diseases. Vulnerability to public health impacts is also very much related to the preparedness and socio-economic status of individual nations, cities, towns, and villages $[9,10]$.

\section{Infrastructure and tourism in the FSM}

In addition to its existing infrastructure, the FSM has received more than \$20 million per year for capital improvements for the fifteen years that the Compact of Free Association Treaty with the USA has been in place. Improvements have been made throughout the four states, in areas such as airports, harbors, roads, telecommunications and utilities. Infrastructure on the other outlying islands is limited to the bare essentials, such as small docks, individual power generators, water catchment systems, and in some cases small airport runways. Electricity $(110-220 \mathrm{~V}, 60$ cycles) is generated throughout the FSM by diesel generators and is primarily available in the four urban centers. Pohnpei has the most reliable electric grid, which is operated independently of the government as a state enterprise fund; the other three states are moving in a similar direction. The existing electrical systems can accommodate additional users and the respective state governments are prepared to provide means of financial assistance when necessary. Only Kosrae and Pohnpei have perennial stream flow, the large deltas of rivers with short stream length and steep channel gradient attest to the very high rainfall which occurs in the mountainous interiors of these islands. All of the communities in the state of Kosrae are served by piped systems, mainly from stream intakes, with subsequent distribution by gravity. In Pohnpei, the capital of Kolonia has a water supply system that consists of a river source (the Nanpil Dam) supplemented by three boreholes which feed the 26-mile long water supply system. Only in the capital center of Weno and on parts of Tonoas in Chuuk State is there a centralized water supply system, and most of the State's population relies on individual roof catchment and storage tanks for their water. This water supply is supplemented by fresh to brackish groundwater from springs and hand-dug wells. In Yap, the Gitan Dam supplies the capital center of Colonia with more than 30 million gallons, but demand currently exceeds the 
capacity of the filtration and chlorination processes at the plant. In addition, there are two deep well systems, one serving the northern areas of Yap Island, and another that distributes spring water which is then fed to the village by gravity on the western side of the island. There are nine interconnected terrestrial ecological zones in the FSM: coastal/littoral beach strand, mangrove forest, swamp forest, freshwater marsh, grassland, secondary forest, primary forest, rain forest and crest forest. All States except Chuuk have large forested areas. Forests account for $63 \%$ of the total land area in Kosrae, 56\% in Pohnpei, and 33\% in Yap, compared with about $10 \%$ in Chuuk. Scattered use of forest resources occurs throughout FSM, mostly for construction in subsistence homesteads and for fire wood, but also for furniture. Mangrove timber is used for handicrafts and furniture. Agricultural production in the FSM is primarily at the subsistence level, but some semi-commercial and commercial activities are undertaken. The few existing commercial fruit and vegetable farms are smaller than 20 acres (about $80,000 \mathrm{~m}^{2}$ ) in size. The fisheries resources of the FSM can be divided into (1) the offshore, deep-sea marine resources of the EEZ (Exclusive Economic Zone), which are primarily exploited by the Distant Water Fishing Nations under license agreements, and (2) the inshore and near-shore marine resources, comprised of fisheries that are exploited primarily for commercial food production. As an industry, tourism is in its infancy, but it is already a significant contributor to the economy of the FSM in terms of employment, export and income. Each of the four major urban centers has an international airport capable of accommodating mid-sized jets, and the air terminals throughout the FSM are being considered for expansion to meet the needs of the steadily increasing air traffic. International and interstate passenger and cargo services are provided by Continental Micronesia's fleet of 737 aircraft. The FSM is served by four international airports. The runways and altitudes of the international airports of Pohnpei, Chuuk, Kosrae and Yap are $1829 \mathrm{~m}$ and $3 \mathrm{~m}, 1831 \mathrm{~m}$ and $3 \mathrm{~m}, 1753 \mathrm{~m}$ and $3 \mathrm{~m}$, and $1829 \mathrm{~m}$ and $28 \mathrm{~m}$, respectively. There are five very small or small ports and harbors in the FMS: Tomil Harbor (anchorage depth 17.1-18.2 m, cargo pier depth 6.4-7.6 m, harbor type: open roadstead), Lele Harbor (Kosrae Island, anchorage depth 12.5-13.7 m, cargo pier depth 7.1-9.1 m, harbor type: coastal natural), Malakai Harbor (anchorage depth 17.1-18.2 m, cargo pier depth 6.4-7.6 m, harbor type: open roadstead), Pohnpei Harbor (Pohnpei Island, anchorage depth $23.2 \mathrm{~m}$, cargo pier depth 9.4-10 m, harbor type: coastal natural) and Port of Moen (Chuuk Island, Cargo pier depth 7.1-9.1 m, harbor type: open roadstead). The FSM has a state-of-the-art telecommunications system offering satellite access for telephone, telex, facsimile, and internet connections/electronic mail to anywhere in the world. It is possible to call each of the FSM states and the mail service to and from the FSM is well developed. The FSM Postal Service picks up and delivers all mail to each of the states by air. The four urban centers of the FSM all have public water and sewerage systems. Outside the urban centers, inhabitants rely on rivers or wells for their freshwater, and they employ different types of septic tank systems for their sewage. Air and ocean transportation to and from the FSM is considered good and the air terminals on the islands are currently being considered for expansion in order to meet the 
needs of the steady increase in air traffic. Each of the ports is capable of handling containerized cargo, with some warehousing and transhipment capabilities also being possible. All ports have cold storage facilities $[3,11]$. The FSM represents one of the last truly unspoiled paradises to be found in the world. A visit to each state in the FSM is to explore four distinctly different worlds. Each state speaks its own language and proudly displays its own traditional cultural heritage. A more traditional island lifestyle prevails, surrounded by the spectacular beauty of the islands and the sea. The FSM attracts the more adventurous traveler, such as experienced sports divers, underwater photographers, hikers, sport fishermen and backpackers. The FSM is actively encouraging the expansion of eco-tourism activities and services to support its objectives of prompting low-impact and culturally sensitive tourism. Associated with the increase in tourism are investment opportunities for larger resorts and hotel development in each of the four states [12]. However, it is important to consider such developments within the contest of disaster prevention, particularly given the problems associated wit5h global warming and rising sea levels.

\section{Concluding remarks}

Leaders and representatives of Japan, Pacific Island Forum members including, Australia, Cook Islands, Federated States of Micronesia, Kiribati, Nauru, New Zealand, Niue, Palau, Papua New Guinea, Republic of the Marshall Islands, Samoa, Solomon Islands, Tonga, Tuvalu and Vanuatsu, as well as the United States gathered for the Sixth Pacific Islands Leaders Meeting (PALM6) on 25 and 26 May 2012 in Okinawa, Japan. The Leaders reiterated the principles of mutual responsibility and ownership of the PALM process. They reaffirmed that Japan, the host country of the PALM, is an equal and important partner sharing the Pacific Ocean, and renewed their commitment to the PALM process. In this connection, reaffirming the strengthened 'Kizuna' (strong bond) in the aftermath of the Great East Japan Earthquake and tsunami, the leaders welcomed that PALM6 was held under the banner of 'We are islanders - For Growing Kizuna in the Pacific'. The leaders from PIF (Pacific Islands Forum) countries noted with satisfaction that the PALM process had greatly contributed to the development of their cooperation with Japan. They welcomed Japan's initiative to invite the United States to PALM6. Recognizing the United States' deep historical ties to the Pacific region, they expressed appreciation for steps the United States has taken to further strengthen its regional engagement. The five areas (1) response to natural disasters, (2) environmental and climate change, (3) sustainable development and human security, (4) people-to-people exchanges, and (5) maritime issues was discussed by leaders [13].

The FSM is composed of groups of small islands in the Western Pacific Ocean. The islands are blessed with abundant marine resources and beautiful natural scenery. However, many of these islands are also threatened by rising sea levels. Rising sea levels promotes coastal erosion, shoreline inundation, and saltwater intrusion, which in turn impact upon crop productivity and freshwater 
availability. To combat these threats, the national and state governments have implemented a number of environmental management plans and initiatives. Taken together, these measures are directed at the effective management and conservation of coral reef ecosystems, coastal zone ecosystems, waste management, upland forest ecosystems, agriculture, forestry, and provision of potable water. Nonetheless, it is important to realize that these initiatives are temporary, and that the larger fundamental issue of global warming remains a threat. In the event that the islands become inundated by seawater, the inhabitants will likely seek refuge in neighboring states. It is therefore essential for developed nations to take the initiative and seek every possible means to prevent further global warming, as doing so will prevent rise of environmental refugee of the western Pacific Ocean who may be left homeless as a result of rising sea levels. In addition, developed countries should accept responsibility for their actions and admit any such refugees in the event that they lose their homelands to rising sea levels caused by global warming.

\section{References}

[1] Wikipedia, the free encyclopedia, Federated States of Micronesia, http://en.wikipedia.org/wiki/Federated-States-of-Micronesia (2012/03/02).

[2] Sea FET Ocean $\mathrm{pH}$ sensor, Sea Level Rise: Weather Underground, http://nihongo.wunderground.com/climate/SeaLevelRise.asp (2012/04/03).

[3] Investment Guide, Federated States of Micronesia, http://www.fsminvest.fm/fsm/guide/overview.html (2012/04/08).

[4] Chuuk (Truk) Visitors Center, Diver's Haven, State of Chuuk, http://www.visit-fsm.org/chuuk/index.html (2012/03/29).

[5] Kosrae Visitors Center, Jewel of Micronesia, State of Kosrae, http://www.visit-fsm.org/kosrae/index.html ( 2012/03/29).

[6] Pohnpei Visitors Center, Garden Island of Micronesia, State of Pohnpei, http://www.visit-fsm.org/pohnpei/index.html (2012/03/29).

[7] Wikipedia, the free encyclopedia, Pohnpei International Airport, http://en.wikipedia.org/wiki/Pohnpei-International-Airport(2012/03/14).

[8] Yap Visitors Center, Land of Stone Money, State of Yap, http://www.visitfsm.org/yap/index.html ( 2012/03/29).

[9] Wikipedia, the free encyclopedia, IPCC Fourth Assessment Report, http://en.wikipedia.org/wiki/IPCC-Fourth-Assessment-Report (2012/04/12).

[10] FSM National Government, 1997 Climate Change National Communication, http://www.sprep.org/att/IRC/eCOPIES/Countries/FSM/ 36.pdf (2012/05/13).

[11] Asian Development Bank, Federated States of Micronesia: Strengthening Infrastructure Planning and Implementation, Asian Development Bank Technical Assistance Report, 2011. http://www.mra.fm/pdfs/idp.pdf $(2012 / 05 / 13)$. 
[12] Investment Guide, Federated States of Micronesia, http://fsminvest.fm/fsm/tourism.html (2012/04/13).

[13] Ministry of Foreign Affairs of Japan, The Sixth Pacific Islands Leaders Meeting (PALM6) Okinawa 'Kizuna' Declaration, http://www.mofa.go.jp/ region/asia-paci/palm/palm6/kizuna_en.html(2012/06/07). 